\title{
Reducing milking frequency from thrice to twice daily in early lactation improves the metabolic status of high-yielding dairy cows with only minor effects on yields
}

\author{
U. Moallem, ${ }^{1 *}$ H. Kamer, ${ }^{1,2}$ A. Hod,${ }^{1,2}$ L. Lifshitz, ${ }^{1}$ G. Kra, ${ }^{1}$ S. Jacoby, ${ }^{1}$ Y. Portnick, ${ }^{1}$ and M. Zachut ${ }^{1}$ \\ ${ }^{1}$ Department of Ruminant Science, Institute of Animal Sciences, The Volcani Center, 68 HaMaccabim Road, Rishon LeZion 7505101, Israel \\ ${ }^{2}$ Department of Animal Science, the Robert H. Smith Faculty of Agriculture, Food and Environment, the Hebrew University of Jerusalem, \\ Rehovot 76100, Israel
}

\section{ABSTRACT}

Reducing milk production during early lactation might be of interest to improve the energy balance (EB) of high-yielding dairy cows. Therefore, the objective of this study was to determine how reducing the milking frequency $(\mathrm{MF})$ of high-yielding dairy cows from thrice to twice a day during the first $30 \mathrm{~d}$ in milk (DIM) affects yields, intake, efficiency, metabolic status, and carryover effects. To this end, 42 multiparous cows were divided into 2 groups according to their previous lactation performance, parity, and body weight. The control cows were milked 3 times a day (3ML) and the treated cows were milked twice a day (2ML) until 30 DIM and then both groups were milked 3 times a day. Milk samples were taken twice a week from 2 or 3 consecutive milkings until 45 DIM for analysis of milk solids, and both groups were followed until 100 DIM to determine the carryover effects of MF until 30 DIM. Individual dry matter intake (DMI), milk yield, and body weight were recorded daily. Blood samples were taken 3 times weekly from $14 \mathrm{~d}$ prepartum until 45 DIM. Milk yield during the first 30 DIM was $8.6 \%$ higher (49.3 and $45.4 \mathrm{~kg} / \mathrm{d}$, respectively), milk fat percentage was lower (3.96 and $4.27 \%$, respectively), and the yields of all milk solids were higher in the $3 \mathrm{ML}$ cows than in the $2 \mathrm{ML}$ cows. Dry matter intake and $4 \%$ fat-corrected milk were similar between groups. The EB during the first 30 DIM was lower in the 3ML cows than in the 2ML cows, and milk yield, but not $4 \%$ fat-corrected milk yield, per unit of DMI was higher in the 3ML cows. No differences were observed between groups from 31 to 100 DIM in milk yield $(\sim 56.3 \mathrm{~kg} / \mathrm{d}$ for both groups), milk solids yield, DMI, or milk/DMI; however, fat percentage was lower and EB was higher in the 3ML cows. Blood glucose concentrations between 0 and

Received March 24, 2019.

Accepted June 18, 2019.

*Corresponding author: uzim@volcani.agri.gov.il
30 DIM were lower and $\beta$-hydroxybutyrate concentrations were higher in the $3 \mathrm{ML}$ cows than in the $2 \mathrm{ML}$ cows, but nonesterified fatty acids concentrations were lower, which may be attributed to the lower clearance frequency of nonesterified fatty acids from the blood stream in the $2 \mathrm{ML}$ cows. A lower proportion of the $3 \mathrm{ML}$ cows $(10 \%)$ ovulated $\leq 15$ DIM compared with the $2 \mathrm{ML}$ cows (40\%), with no beneficial effects on preovulatory follicle characteristics. Reducing the MF from thrice to twice a day during the first 30 DIM improved $\mathrm{EB}$ and metabolic status, with only minor effects on production.

Key words: milking frequency, energy balance, metabolic status

\section{INTRODUCTION}

Negative energy balance (NEB), which occurs in early lactation in high-yielding dairy cows, is associated with an increase in the incidence of metabolic disorders (Grummer, 1993; Esposito et al., 2014) and reduced fertility (Lucy, 2001; Butler, 2003). Hence, improving energy balance (EB) during early lactation is of great interest. There are 3 main approaches to improving EB: (1) increasing energy input, which includes enhancing energy consumption and, to some extent, improving the metabolism; (2) decreasing energy output, which means reducing the total energy produced in milk (or body mass); and (3) optimizing body tissue reserves at calving (BCS) to avoid massive body tissue mobilization postpartum (PP; Morrow, 1976). Several nutritional manipulations to alleviate NEB during early lactation by increasing energy input have been tested with mixed results. The most common nutritional strategy that has been intensely investigated is to increase the fat content of the cow's fresh diet to enhance energy density and possibly energy consumption. However, this strategy was not effective in reducing adipose body mobilization and the concentrations of plasma nonesterified fatty acids (NEFA; Chilliard, 1993; Beam and Butler, 1998; 
Bertics and Grummer, 1999). This was mainly because fat supplementation stimulated milk production (Sklan et al., 1991; Chilliard, 1993) or sometimes decreased DMI (Chilliard, 1993; Beam and Butler, 1998; Moallem et al., 2007) and consequently was not effective in improving EB. In a review paper, Leroy et al. (2014) concluded that dietary fat supplementation has no added value in alleviating NEB during the transition period in high-producing dairy cows. Another strategy tested was to increase the glucogenic precursor's consumption during the transition period. In a study by Moallem et al. (2007), cows were supplemented with propylene glycol from $21 \mathrm{~d}$ prepartum through 21 DIM, but no improvement in EB was achieved. In a study by Butler et al. (2006), cows were drenched daily with propylene glycol from d 10 prepartum until d $25 \mathrm{PP}$; the metabolic status of the cows improved but with no beneficial effect on the reproductive system. Other efforts attempted to alleviate EB during the transition period, such as reducing milk energy output by supplementing the isomers of CLA, which are potent inhibitors of mammary lipid synthesis; however, this approach achieved very limited results (Bernal-Santos et al., 2003; Shingfield et al., 2004; Castañeda-Gutiérrez et al., 2005).

The relative failure to improve EB through nutritional manipulation led to efforts to develop other management strategies to achieve this goal. Shortening the dry period has been proposed as a management strategy to improve the EB of dairy cows in early lactation (Grummer and Rastani, 2004). Cows with continuous milking or a short dry period produced 12 to $25 \%$ less milk in the subsequent lactation; however, these cows also had less severe negative EB PP compared with cows with a traditional dry period length $(\sim 60 \mathrm{~d}$; Rastani et al., 2005). This was also demonstrated by reduced PP plasma NEFA and liver triglyceride (TG) concentrations (Rastani et al., 2005), with a beneficial effect on the reproductive system (Gümen et al., 2005). The relatively great loss in milk yield and other relevant aspects, such as the effect of continuous milking or a short dry period on animal welfare, preclude adopting this management strategy as a viable practice in the field.

Increasing milking frequency (MF) is well established as a management tool to increase milk production in dairy cows, which has a central effect on EB. Erdman and Varner (1995) found a fixed milk yield response, with an increase of $3.5 \mathrm{~kg} / \mathrm{d}$, when MF was increased from twice to thrice a day regardless of the yield for cows milked twice daily. Dairy cows in Israel are commonly milked 3 times a day. We therefore hypothesized that in high-yielding dairy cows the magnitude of the decrease in milk yield when reducing MF from thrice to twice a day in early lactation would be small but might be effective in alleviating EB. Hence, the objective of the present study was to examine how reducing the MF of multiparous high-yielding dairy cows from thrice to twice daily during the first 30 DIM affected milk and milk solids yields, feed intake, efficiency, EB, and metabolic status as well as the reproductive system. In addition, we followed the cows until 100 DIM to determine any potential carryover effects of reduced MF during the early PP period.

\section{MATERIALS AND METHODS}

The experimental protocol and procedures were approved by the Volcani Center Animal Care Committee (IL 637/16). The study was conducted at the experimental dairy farm of the Volcani Center in Rishon LeZion, Israel. Forty-two high-yielding multiparous Israeli-Holstein pregnant cows were stratified into 2 treatment groups at $256 \mathrm{~d}$ of pregnancy, blocked on milk production and fat content during the first 120 $\mathrm{d}$ of the previous lactation, parity, BW at drying-off, and the expected time of the approaching parturition. The cows were group housed at $256 \mathrm{~d}$ of pregnancy in a shaded loose pen that was equipped with a real-time electronic individual feeding system and fed a drycow diet. Each feeding station included an individual identification system (ID tag; S.A.E. Afikim, Kibbutz Afikim, Israel) that allowed each cow to enter a specific feeding station and automatically recorded each meal. The calving period continued for 2 mo. Immediately after calving, the cows were moved to the side of the same barn housing the lactating cows. The cows were divided into 2 subgroups: the control cows were milked thrice a day (3ML; at 0050, 1300, and $2000 \mathrm{~h}$ ) and the treatment cows were milked twice a day $(\mathbf{2 M L}$; at 0700 and 1900 h) until 30 DIM. From 30 DIM, the 2ML cows joined the 3ML cow group, and all cows were then milked 3 times a day. The cows were followed until 100 DIM to determine the carryover effects. Milk samples were taken twice a week (on Monday and Thursday) from d 5 after calving until 30 DIM from 2 consecutive milkings for the 2ML cows or 3 consecutive milkings for the 3ML cows. From 30 to 45 DIM, milk samples were taken twice a week and then monthly from 3 consecutive milkings until 100 DIM. The milk samples were analyzed for milk fat, protein, lactose, and urea by infrared analysis (standard IDF 141C:2000; IDF, 2000) at the laboratories of the Israeli Cattle Breeders' Association (Caesarea, Israel). Somatic cell counts were also determined in the same laboratory.

Cows were automatically weighed 3 times daily, after each milking, with a walk-on electronic scale (S.A.E. Afikim). We also determined the average BW at wk 1, 5 , and 15 for each cow using daily records and then cal- 
culated the individual gain between these time points. The cows were also equipped with collar-mounted tags (HR-Tags; SCR Engineers Ltd., Hadarim, Netanya, Israel) that monitored and transmitted their rumination time. Rumination data were recorded automatically and stored in 2-h blocks. The cows were also equipped with a PlusTM sensor (S.A.E. Afikim), which monitored their activity (steps/h) and lying time (min). The BCS of cows (scale of 1 to 5; Edmonson et al., 1989) was determined weekly by 1 technician from $21 \mathrm{~d}$ prepartum to $100 \mathrm{PP}$.

Postpartum, the cows were fed a standard Israeli milking cow ration. The composition and content of the diet are presented in Table 1 . The diet was offered once daily at $1000 \mathrm{~h}$ ad libitum to about $5 \%$ orts. The individual amounts offered and the daily leftovers were recorded daily to calculate individual feed intake. The diet was sampled weekly and dried at $60^{\circ} \mathrm{C}$ for $48 \mathrm{~h}$ for DM determination.

Blood samples were taken 3 times weekly (Sunday, Tuesday, and Thursday) from $14 \mathrm{~d}$ before the expected calving date until 45 DIM. The blood samples were collected by coccygeal venipuncture after the morning milking into vacuum tubes containing lithium heparin (Becton Dickinson, Cowley, UK), and tubes were

Table 1. Ingredients and chemical composition of the diet

\begin{tabular}{lc}
\hline Item & Value \\
\hline Ingredient, \% of DM & \\
Corn, ground & 20.2 \\
Barley, rolled & 3.3 \\
Wheat grain, rolled & 4.8 \\
Rapeseed meal & 7.1 \\
Whole cottonseed & 2.1 \\
Gluten feed & 14.8 \\
Wheat silage & 10.8 \\
Corn silage & 14.2 \\
Oat hay & 9.0 \\
Dried distillers grains & 8.9 \\
Mother liquor ${ }^{1}$ & 0.6 \\
Calcium salt of fatty acids & 1.0 \\
Urea & 0.3 \\
Bicarbonate & 1.0 \\
Limestone & 0.4 \\
NaCl & 1.4 \\
Vitamins and minerals ${ }^{2}$ & 0.1 \\
Chemical composition & \\
NE ${ }^{3}$ Mcal/kg of DM & 1.78 \\
CP, \% & 16.5 \\
NDF, \% & 32.2 \\
Forage NDF, \% & 17.5 \\
Total fat (ether extract), \% & 4.9 \\
Ca, \% & 0.009 \\
P, \% & 0.005 \\
\hline Dary ind &
\end{tabular}

${ }^{1}$ Dairy industry byproduct.

${ }^{2}$ Containing (per kg of DM) 20,000,000 IU of vitamin A; 2,000,000 IU of vitamin D; 15,000 IU of vitamin E; 6,000 $\mathrm{mg}$ of $\mathrm{Mn} ; 6,000 \mathrm{mg}$ of $\mathrm{Zn}$; $2,000 \mathrm{mg}$ of $\mathrm{Fe} ; 1,500 \mathrm{mg}$ of $\mathrm{Cu} ; 120 \mathrm{mg}$ of I; $50 \mathrm{mg}$ of Se; $20 \mathrm{mg}$ of $\mathrm{Co}$

${ }^{3}$ Based on NRC (1989) values of individual ingredients. immediately placed in ice. Plasma was separated by centrifugation at $1,000 \times g$ for $15 \mathrm{~min}$ at $4^{\circ} \mathrm{C}$, divided into 4 tubes, and stored at $-80^{\circ} \mathrm{C}$ pending analysis. Concentrations of glucose, NEFA, BHB, TG, and aspartate aminotransferase (AST) were determined in blood prepartum and $\mathrm{PP}$, and progesterone blood concentrations were determined from 7 to 45 DIM to determine the cyclicity resumption PP.

\section{Energy Calculations}

Energy-corrected milk and EB were calculated according to NRC (2001) as follows:

$$
\begin{gathered}
\mathrm{NE}_{\mathrm{C}}(\mathrm{Mcal} / \mathrm{d})=\mathrm{NE}_{\mathrm{L}} / \mathrm{kg} \text { of } \mathrm{DM} \times \mathrm{DMI} \\
\mathrm{NE}_{\mathrm{M}}(\mathrm{Mcal} / \mathrm{d})=\mathrm{BW}^{0.75} \times 0.08 \\
\mathrm{ECM}(\mathrm{Mcal} / \mathrm{d})=\text { milk }(\mathrm{kg}) \times[(0.0929 \times \text { fat } \%) \\
+(0.0547 \times \text { protein } \%)+(0.0395 \times \text { lactose } \%)] \\
\mathrm{EB}(\mathrm{Mcal} / \mathrm{d})=\mathrm{NE}_{\mathrm{C}}-\left(\mathrm{NE}_{\mathrm{M}}+\mathrm{ECM}\right),
\end{gathered}
$$

where $\mathrm{NE}_{\mathrm{C}}=$ net energy consumed and $\mathrm{ECM}=$ net energy output in milk. The $\mathrm{NE}_{\mathrm{L}}$ values for feedstuffs used in the formulated diets were calculated using NRC (1989) values with a few adjustments.

\section{Ovarian Ultrasonography}

From d 9 to $11 \mathrm{PP}$, the ovarian follicular activity of 8 cows from each group was examined twice a week using a MylbFive linear array ultrasonography transducer (Pie Medical, Maastricht, the Netherlands) until the day of the first ovulation, followed by the corpus luteum existence, or 34 DIM. At each monitoring, the follicles on both ovaries were counted according to the following criteria: 3 - to 5 -mm follicles (class 1), 6- to 9 -mm follicles (class 2), and $\geq 10$-mm follicles (class 3 ). Follicular cysts were defined as nonovulatory follicles that were $\geq 25 \mathrm{~mm}$ in diameter and that persisted for $\geq 10 \mathrm{~d}$.

In addition, blood samples from all cows from $7 \mathrm{~d}$ PP and later were analyzed for progesterone concentrations to determine the time of the first ovulation PP. The first ovulations afterward were estimated to occur $3 \mathrm{~d}$ before the first PP increase in progesterone $\geq 1 \mathrm{ng} / \mathrm{mL}$.

\section{Follicular Fluid Aspiration}

Follicular fluid (FF) aspiration from preovulatory follicles was performed between 60 and 80 DIM in 8 cows from each group that was randomly selected to 
assess the effect of a different MF on the characteristics of preovulatory follicles. Ovaries of cows were monitored with a Aquila 5-MHz linear array ultrasonography transducer (Pie Medical) at 50 DIM, and cows that were confirmed as cycling by the presence of a corpus luteum $(\mathbf{C L})$ were treated intramuscularly with a $\mathrm{PGF}_{2 \alpha}$ analog (cloprostenol sodium, Estroplan; Parnell Living Science, Alexandria, NSW, Australia) at a dosage of $500 \mu \mathrm{g} / \mathrm{cow}$. The cows were examined for signs of estrus, and at 14 to $15 \mathrm{~d}$ after a visible behavioral estrus, they received another $\mathrm{PGF}_{2 \alpha}$ injection followed by $\mathrm{FF}$ aspiration after $48 \mathrm{~h}$. Cows that were not confirmed as cycling by CL presence at 50 DIM were treated with a GnRH analog consisting of 200 $\mu \mathrm{g}$ of gonadorelin acetate (Gonabreed; Parnell Living Science). Ten days after the GnRH injection, the cows were monitored with ultrasound. After the presence of $\mathrm{CL}$ was confirmed they were injected with a $\mathrm{PGF}_{2 \alpha}$ analog, and 14 to $15 \mathrm{~d}$ after a visible behavioral estrus they received another $\mathrm{PGF}_{2 \alpha}$ injection, followed by $\mathrm{FF}$ aspiration after $48 \mathrm{~h}$.

Forty-eight hours after the second $\mathrm{PGF}_{2 \alpha}$ administration, we performed FF aspiration as described by Moallem et al. (1999). Briefly, the cows were sedated with an intramuscular administration of $1 \mathrm{~mL}$ of $2 \%$ Sedaxylan (xylazine base, $20 \mathrm{mg} / \mathrm{mL}$; Eurovet Animal Health, AE Bladel, the Netherlands) and were given a local anesthesia in the form of $5 \mathrm{~mL}$ of $2 \%$ lidocaine $\mathrm{HCl}$ (200 mg/10 mL; Esracain 2\%; Rafa Laboratories, Jerusalem, Israel) injected epidurally between the last sacral and the first caudal vertebrae in the sacrococcygeal space. Ovaries were monitored, and follicles $\geq 7$ $\mathrm{mm}$ in diameter were aspirated separately. The FF was aspirated with the aid of an ultrasound scanner (Pie Medical) connected to a $7.5-\mathrm{MHz}$ vaginal sector transducer equipped with a needle guide and an MP86 suction pump (Biometra, Goettingen, Germany) set at a flow rate of 25 to $30 \mathrm{~mL} / \mathrm{min}$. The needles used were 18 gauge and were changed between follicles. After collection, the $\mathrm{FF}$ was centrifuged at $3,000 \times g$ for $15 \mathrm{~min}$ at $4^{\circ} \mathrm{C}$, separating the sediment, including granulosa cells, which was separated from the fluids, and both fractions were frozen at $-32^{\circ} \mathrm{C}$ pending analysis. Jugular venous blood samples were collected in lithium heparin-coated vacuum tubes (Becton Dickinson, Cowley, UK) on the day of the second $\mathrm{PGF}_{2 \alpha}$ treatment and $48 \mathrm{~h}$ later (i.e., in parallel with the aspiration of the preovulatory follicles) to verify that the cows were in the expected stage of the estrous cycle.

\section{Chemical Analysis}

The dried diet samples were analyzed for their content of N (AOAC, 1990, method 984.13; Kjeltec 8400
Analyzer, Foss Analytical AB, Höganäs, Sweden), NDF, and ADF (equipment from Ankom Technology, Fairport, NY) using $\alpha$-amylase and sodium sulfite for NDF according to Van Soest et al. (1991); Ca (AOAC, 1990, method 935.13); P (AOAC, 1990, method 964.06); and ether extracts (AOAC, 1990, method 996.06). Samples were dried at $550^{\circ} \mathrm{C}$ for $3 \mathrm{~h}$ for ash determination. National Research Council (1989) $\mathrm{NE}_{\mathrm{L}}$ values of feedstuffs were used.

The concentrations of NEFA in plasma were determined with an NEFA C Test Kit (Wako Chemicals GmbH, Neuss, Germany). The intra- and interassay coefficients of variation for the NEFA assay were 5.9 and $6.1 \%$, respectively.

The plasma BHB concentration was determined with a Ranbut D-3-Hydroxybutyrate kit (Randox, Crumlin, UK) in which a reaction of 3-hydroxybutyrate and dehydrogenase generated a UV emission that was correlated with the sample's BHB concentration. The samples were examined at $340 \mathrm{~nm}$ with an optical density reader, and the results were calibrated against known BHB concentrations. The intra- and interassay coefficients of variation for the BHB assay were 1.3 and $1.6 \%$, respectively. Glucose, TG, and AST concentrations in plasma were analyzed using the Cobas C111 Autoanalyser (Roche Holding GmbH, GrenzachWyhlen, Germany) using appropriate reagents.

The FF of all aspirated preovulatory follicles $(\mathrm{n}=$ 40) was assessed for the relevant concentrations of progesterone $\left(\mathbf{P}_{4}\right)$ and estrogen $\left(\mathbf{E}_{2}\right.$; Progest-RIA and Ester-CTRIA, respectively; Cisbio Bioassays, Parc Marcel Boiteux, France) as well as androstenedione ( $\mathbf{A}_{4} ;$ Immunotech s.r.o, Prague, Czech Republic). All FF samples were diluted 100-, 500-, or 30-fold for the $\mathrm{P}_{4}, \mathrm{E}_{2}$, and $\mathrm{A}_{4}$ assays, respectively, so that the assay results matched the detection ranges.

The minimal detectable concentrations of $\mathrm{P}_{4}, \mathrm{E}_{2}$, and $\mathrm{A}_{4}$ were $0.2,20$, and $0.1 \mathrm{ng} / \mathrm{mL}$, respectively. The intra-assay and interassay coefficients of variation for the $\mathrm{P}_{4}, \mathrm{E}_{2}$, and $\mathrm{A}_{4}$ assays were $9.1,4.0$, and $6.0 \%$ and 8.4, 3.4, and $4.3 \%$, respectively. We considered follicles with $\mathrm{E}_{2}: \mathrm{P}_{4}$ ratios $>1$ to be $\mathrm{E}_{2}$ active (Ireland and Roche, 1982) and subjected them to further analysis and evaluation. The $\mathrm{P}_{4}$ concentration in blood was determined using the same kit (Progest-RIA; Cisbio Bioassays) with a $\mathrm{P}_{4}$ detection threshold of $0.2 \mathrm{pg} / \mathrm{mL}$.

\section{Statistical Analysis}

Production, EB, and efficiency calculations were analyzed as 3 periods - 0 to 30 DIM (period 1), 31 to 100 DIM (period 2), and 0 to 100 DIM - for determining the effects of the whole period on production and efficiency. Continuous variables (milk, milk solids, DMI, 
Table 2. Milk and milk solids yields from 0 to 30 and 31 to 100 DIM for high-yielding dairy cows milked thrice daily (3ML) or twice daily (2ML) from calving until 30 DIM and then milked 3 times daily

\begin{tabular}{|c|c|c|c|c|c|c|c|c|}
\hline Item & \multicolumn{2}{|c|}{ 0-30 DIM } & \multicolumn{2}{|c|}{ 31-100 DIM } & SEM & \multicolumn{3}{|c|}{$P$-value } \\
\hline Milk, kg/d & $49.3^{\mathrm{b}}$ & $45.4^{\mathrm{c}}$ & $56.4^{\mathrm{a}}$ & $56.2^{\mathrm{a}}$ & 0.3 & $>0.001$ & $>0.001$ & $>0.001$ \\
\hline Fat, $\%$ & $3.96^{\mathrm{b}}$ & $4.27^{\mathrm{a}}$ & $3.87^{\mathrm{b}}$ & $4.09^{\mathrm{ab}}$ & 0.07 & $>0.001$ & 0.17 & 0.39 \\
\hline Protein, \% & 3.28 & 3.27 & 3.20 & 3.19 & 0.32 & 0.75 & 0.07 & 0.91 \\
\hline Lactose, \% & $4.93^{\mathrm{bc}}$ & $4.87^{\mathrm{c}}$ & $5.03^{\mathrm{a}}$ & $4.94^{\mathrm{b}}$ & 0.03 & 0.007 & 0.04 & 0.64 \\
\hline Fat, $\mathrm{kg} / \mathrm{d}$ & $2.06^{\mathrm{ab}}$ & $1.92^{\mathrm{c}}$ & $2.04^{\text {abc }}$ & $2.15^{\mathrm{a}}$ & 0.04 & 0.58 & 0.08 & 0.001 \\
\hline $4 \% \mathrm{FCM}, \mathrm{kg} / \mathrm{d}$ & $46.5^{\mathrm{c}}$ & $45.8^{\mathrm{c}}$ & $52.6^{\mathrm{b}}$ & $55.3^{\mathrm{a}}$ & 0.4 & 0.002 & $<0.001$ & $<0.001$ \\
\hline $\mathrm{ECM}, \mathrm{kg} / \mathrm{d}$ & $36.6^{\mathrm{c}}$ & $34.3^{\mathrm{d}}$ & $40.0^{\mathrm{b}}$ & $40.8^{\mathrm{a}}$ & 0.3 & 0.001 & $<0.001$ & $<0.001$ \\
\hline MUN, mg/dL & $15.8^{\mathrm{b}}$ & $17.2^{\mathrm{a}}$ & $17.0^{\mathrm{ab}}$ & $16.4^{\mathrm{ab}}$ & 0.5 & 0.34 & 0.80 & 0.02 \\
\hline
\end{tabular}

${ }^{\mathrm{a}-\mathrm{d}}$ Within rows, means with different superscript letters are statistically different.

${ }^{1}$ Milking frequency until 30 DIM.

and efficiency calculations) were analyzed as repeated measurements with PROC MIXED of SAS version 9.2 (SAS Institute, 2002). When relevant, variables were analyzed using the specific data of the previous lactation data as covariates.

The model used was as follows:

$$
\begin{aligned}
\mathrm{Y}_{\mathrm{ijkl}} & =\mu+\mathrm{T}_{\mathrm{i}}+\mathrm{L}_{\mathrm{j}}+\mathrm{C}(\mathrm{T} \times \mathrm{L})_{\mathrm{ijk}}+\mathrm{P}_{\mathrm{l}} \\
& +\mathrm{TP}_{\mathrm{m}}+\mathrm{DIM}_{\mathrm{ijklmn}}+E_{\mathrm{ijk} l m n o},
\end{aligned}
$$

where $Y_{\mathrm{ijk}}=$ dependent variable; $\mu=$ overall mean; $\mathrm{T}_{\mathrm{i}}=$ treatment effect $(\mathrm{i}=1$ to 2$) ; \mathrm{L}_{\mathrm{j}}=$ parity $(\mathrm{j}=2$ or $>2) ; \mathrm{C}(\mathrm{T} \times \mathrm{L})_{\mathrm{ijk}}=$ cow $\mathrm{k}$ nested in treatment $\mathrm{i}$ and parity $\mathrm{j} ; \mathrm{P}_{1}=$ period effect; $\mathrm{TP}_{\mathrm{m}}=$ treatment $\times$ period; $\mathrm{DIM}_{\mathrm{ijklmn}}=$ day with milk as a continuous variable; and $E_{\mathrm{ijklmno}}=$ random residual. The treatment $\times$ DIM interaction was tested and found to be not significant and therefore was excluded from the model. For the 0 to 100 DIM analysis, the effects of period and treatment $\times$ period were removed from the model.

Metabolite concentrations in blood were analyzed for 2 periods (0-30 DIM and 31-50 DIM) for determining the carryover effects using the above model. Body weight gain was analyzed using PROC GLM of SAS version 9.2 (SAS Institute, 2002). Distributions of ovulation onset were analyzed using PROC FREQ of SAS version 9.2 (SAS Institute, 2002). Least squares means and adjusted SEM are presented in Tables 2, 3, 4,5 , and $6 ; P<0.05$ was accepted as significant unless otherwise stated.

\section{RESULTS}

Milk and milk solid yields are presented in Table 2 . Milk yield was $8.6 \%$ greater from 0 to 30 DIM in the $3 \mathrm{ML}$ cows than in the 2ML cows $(P<0.001$ : Figure

Table 3. Dry matter intake, energy balance, and efficiency calculations from 0 to 30 and 31 to 100 DIM for high-yielding dairy cows milked

\begin{tabular}{|c|c|c|c|c|c|c|c|c|}
\hline Item & \multicolumn{2}{|c|}{ 0-30 DIM } & \multicolumn{2}{|c|}{ 31-100 DIM } & SEM & \multicolumn{3}{|c|}{$P$-value } \\
\hline DMI, $\mathrm{kg} / \mathrm{d}$ & 27.8 & 27.9 & 31.5 & 31.0 & 0.2 & 0.22 & $>0.001$ & 0.07 \\
\hline Milk/DMI, ${ }^{2} \mathrm{~kg} / \mathrm{kg}$ & $1.83^{\mathrm{a}}$ & $1.68^{\mathrm{b}}$ & $1.83^{\mathrm{a}}$ & $1.85^{\mathrm{a}}$ & 0.01 & $<0.001$ & $<0.001$ & $<0.001$ \\
\hline $4 \% \mathrm{FCM} / \mathrm{DMI},{ }^{3} \mathrm{~kg} / \mathrm{kg}$ & $1.71^{\mathrm{b}}$ & $1.70^{\mathrm{b}}$ & $1.70^{\mathrm{b}}$ & $1.81^{\mathrm{a}}$ & 0.01 & 0.001 & 0.005 & $<0.001$ \\
\hline $\mathrm{ECM} / \mathrm{DMI},{ }^{4} \mathrm{Mcal} / \mathrm{kg}$ & $1.36^{\mathrm{a}}$ & $1.29^{\mathrm{b}}$ & $1.29^{\mathrm{b}}$ & $1.35^{\mathrm{a}}$ & 0.01 & 0.85 & 0.98 & $<0.001$ \\
\hline
\end{tabular}
thrice daily (3ML) or twice daily (2ML) from calving until 30 DIM and then milked 3 times daily

\footnotetext{
${ }^{\mathrm{a}-\mathrm{d}}$ Within rows, means with different superscript letters are statistically different.

${ }^{1}$ Milking frequency until 30 DIM.

${ }^{2}$ Milk yield $(\mathrm{kg} / \mathrm{d})$ divided by DMI $(\mathrm{kg} / \mathrm{d})$.

${ }^{3} 4 \%$ FCM $(\mathrm{kg} / \mathrm{d})$ divided by DMI $(\mathrm{kg} / \mathrm{d})$.

${ }_{4}^{4} \%$ ECM (Mcal/d) divided by DMI $(\mathrm{kg} / \mathrm{d})$.
} 
Table 4. Milk and milk solids yields and efficiency calculations from 0 to 100 DIM for high-yielding dairy cows milked thrice daily (3ML) or twice daily (2ML) from calving until 30 DIM and then milked 3 times daily

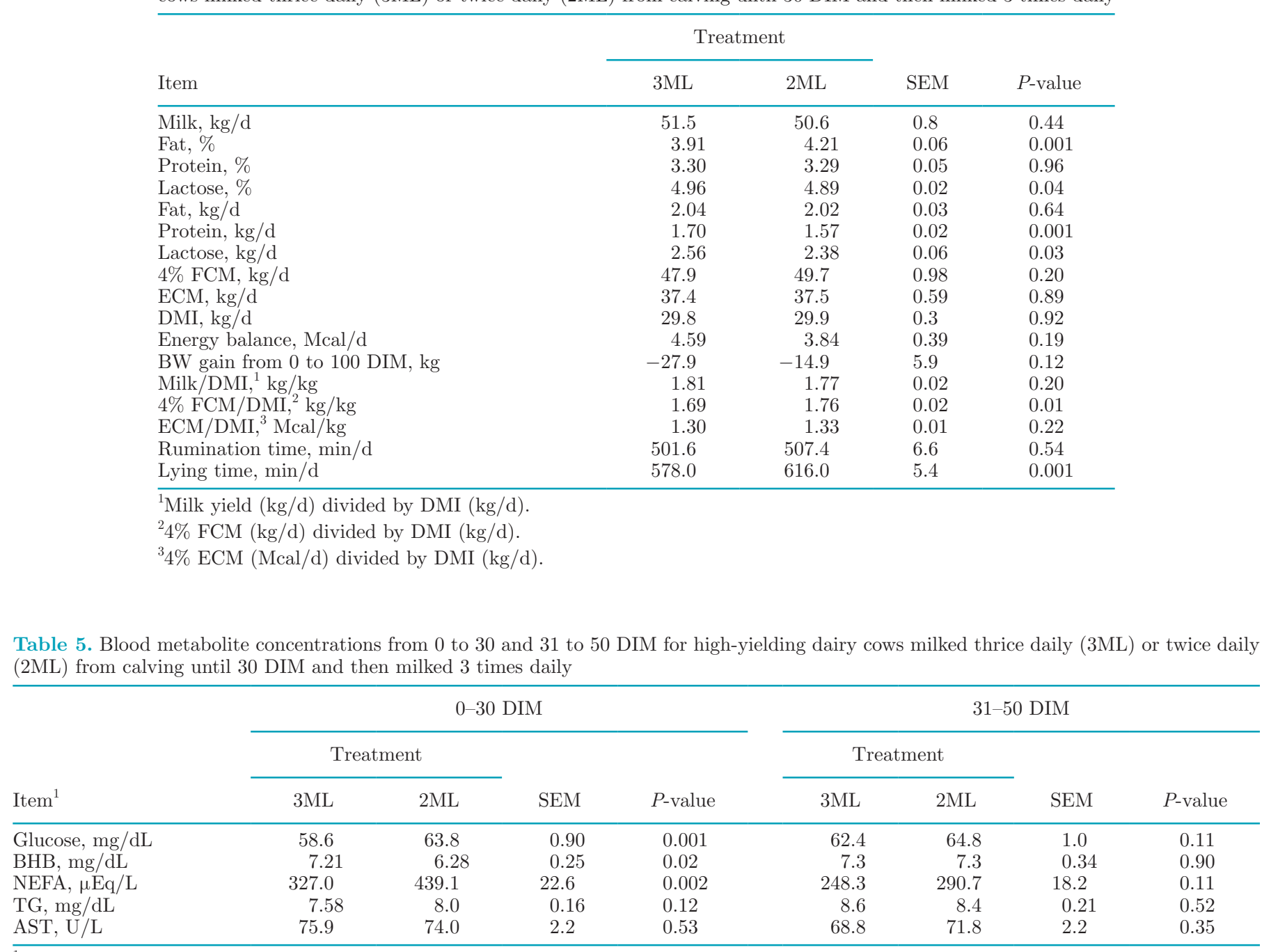

(2ML) from calving until 30 DIM and then milked 3 times daily

${ }^{1} \mathrm{NEFA}=$ nonesterified fatty acids; $\mathrm{TG}=$ triglyceride; $\mathrm{AST}=$ aspartate aminotransferase.

Table 6. Concentrations of progesterone, androstenedione, and estradiol in estrogen-active follicles aspirated from high-yielding dairy cows milked thrice daily (3ML) or twice daily (2ML) from calving until 30 DIM and then milked 3 times daily ${ }^{1}$

\begin{tabular}{|c|c|c|c|c|}
\hline \multirow[b]{2}{*}{ Item } & \multicolumn{2}{|c|}{ Treatment } & \multirow[b]{2}{*}{ SEM } & \multirow[b]{2}{*}{$P$-value } \\
\hline & $3 \mathrm{ML}$ & $2 \mathrm{ML}$ & & \\
\hline Cows, no. & 8 & 8 & & \\
\hline Follicles aspirated, no. & 21 & 19 & & \\
\hline Atretic follicles, no. & 8 & 11 & & \\
\hline Estrogen-active follicles, no. & 13 & 9 & & \\
\hline Diameter of aspirated follicles, $\mathrm{mm}$ & 12.9 & 11.4 & 0.88 & 0.82 \\
\hline Volume of aspirated follicles, $\mathrm{mL}$ & 1.55 & 1.61 & 0.30 & 0.93 \\
\hline Progesterone, $\mathrm{ng} / \mathrm{mL}$ & 49.4 & 55.1 & 14.1 & 0.78 \\
\hline Androstenedione, $\mathrm{ng} / \mathrm{mL}$ & 55.9 & 70.5 & 17.5 & 0.56 \\
\hline Estradiol, $\mathrm{ng} / \mathrm{mL}$ & $1,509.4$ & $1,948.5$ & 265.0 & 0.26 \\
\hline Estradiol:progesterone ratio & 56.9 & 45.6 & 12.5 & 0.53 \\
\hline Total estradiol content, $\mu \mathrm{g}$ & 2.57 & 3.78 & 1.1 & 0.46 \\
\hline Total progesterone content, $\mu \mathrm{g}$ & 0.14 & 0.10 & 0.07 & 0.70 \\
\hline Total androstenedione content, $\mu \mathrm{g}$ & 0.08 & 0.16 & 0.05 & 0.23 \\
\hline
\end{tabular}

${ }^{1}$ Preovulatory follicles were aspirated $48 \mathrm{~h}$ after prostaglandin injection from 8 cows from each group. 
1A) but was similar between groups from 31 to 100 DIM $(P=0.51)$. The effects of period and treatment $\times$ period for milk yield were significant $(P<0.001)$. Fat content was 0.31 percentage units lower from 0 to $30 \mathrm{DIM}$ in the $3 \mathrm{ML}$ cows than in the 2ML cows $(P$ $=0.001)$, whereas it was 0.22 percentage units lower from 31 to 100 DIM in the $3 \mathrm{ML}$ cows $(P=0.03)$. The effect of period and treatment $\times$ period for fat content was not significant. Protein content in milk was not different between groups in both periods, and the effect of period and treatment $\times$ period was not significant. Lactose percentage until 30 DIM tended to be higher in the 3ML cows $(P=0.07)$ and was significantly higher than in the 2ML cows from 31 to 100 DIM $(P=0.04)$. Fat yield $(\mathrm{kg} / \mathrm{d})$ until 30 DIM was higher in the $3 \mathrm{ML}$ cows $(P=0.003)$, but from 31 to 100 DIM fat yield tended to be lower in the 3ML cows $(P=0.07)$. The effect of period on fat yield tended to be higher $(P=$ $0.08)$, and the effect of treatment $\times$ period was significantly higher $(P=0.001)$. Protein and lactose yields were higher in the $3 \mathrm{ML}$ cows from 0 to 30 DIM, but from 31 to 100 DIM they were similar.

The $4 \%$ FCM yield from 0 to 30 DIM was similar between groups but was $5.1 \%$ higher from 31 to 100 DIM in the $2 \mathrm{ML}$ cows $(P<0.001$; Figure $1 \mathrm{~B})$. The effects of period and treatment $\times$ period for $4 \% \mathrm{FCM}$ yield were significant $(P<0.001)$. The ECM yield from 0 to 30 DIM was higher in the $3 \mathrm{ML}$ group $(P<0.001$; Figure 1C) but from 31 to 100 DIM was higher in the $2 \mathrm{ML}$ cows $(P=0.001)$. The MUN was $8.9 \%$ higher in the 2ML cows during the first 30 DIM $(P=0.002)$ but was similar between groups from 31 to 100 DIM.

The DMI from 0 to 30 DIM was similar between groups (Table 3; Figure 2A) but was higher in the 3ML cows between 31 and 100 DIM $(P=0.009)$. The effect of period on DMI was significant $(P<0.001)$, and the treatment $\times$ period interaction tended to be higher $(P=0.07)$. The average EB was higher from 0 to 30 DIM in the 2ML cows than in the 3ML cows $(P<$ 0.001; Figure 2B), but from 31 to 100 DIM the EB was higher in the 3ML cows than in the $2 \mathrm{ML}$ cows $(P<$ 0.001). The effects of period and treatment $\times$ period on EB were significant $(P<0.001)$. No differences were observed between groups in BCS measurements (data not presented). The milk yield per unit of DMI (milk/ DMI) until 30 DIM was higher in the 3ML cows $(P<$ 0.001 ) and from 31 to 100 DIM it tended to be higher in the 3ML cows $(P=0.1)$. The effects of period and treatment $\times$ period interaction on milk/DMI ratio were significant $(P<0.001)$. The $4 \% \mathrm{FCM}$ yield per unit of DMI (FCM/DMI) was not different between groups until 30 DIM, but from 31 to 100 DIM it was higher in the 2ML cows $(P<0.001)$. The effect of period and treatment $\times$ period interaction on $\mathrm{FCM} / \mathrm{DMI}$ ratio was significant $(P<0.005)$. The ECM yield $(\mathrm{Mcal} / \mathrm{d})$ per unit of DMI (ECM/DMI) until 30 DIM was higher in the 3ML cows $(P<0.001)$, but from 31 to 100 DIM it was higher in the 2ML cows $(P<0.001)$. The effect of period on ECM/DMI was not significant, but the treatment $\times$ period interaction was significant $(P<$ 0.001). A similar result was found for the conversion ratio between the energy intake and ECM (data not shown). The daily rumination time until 30 DIM was similar between groups, but from 31 to 100 DIM it was higher in the $2 \mathrm{ML}$ cows $(P=0.03)$. The effect of period on rumination time and the treatment $\times$ period
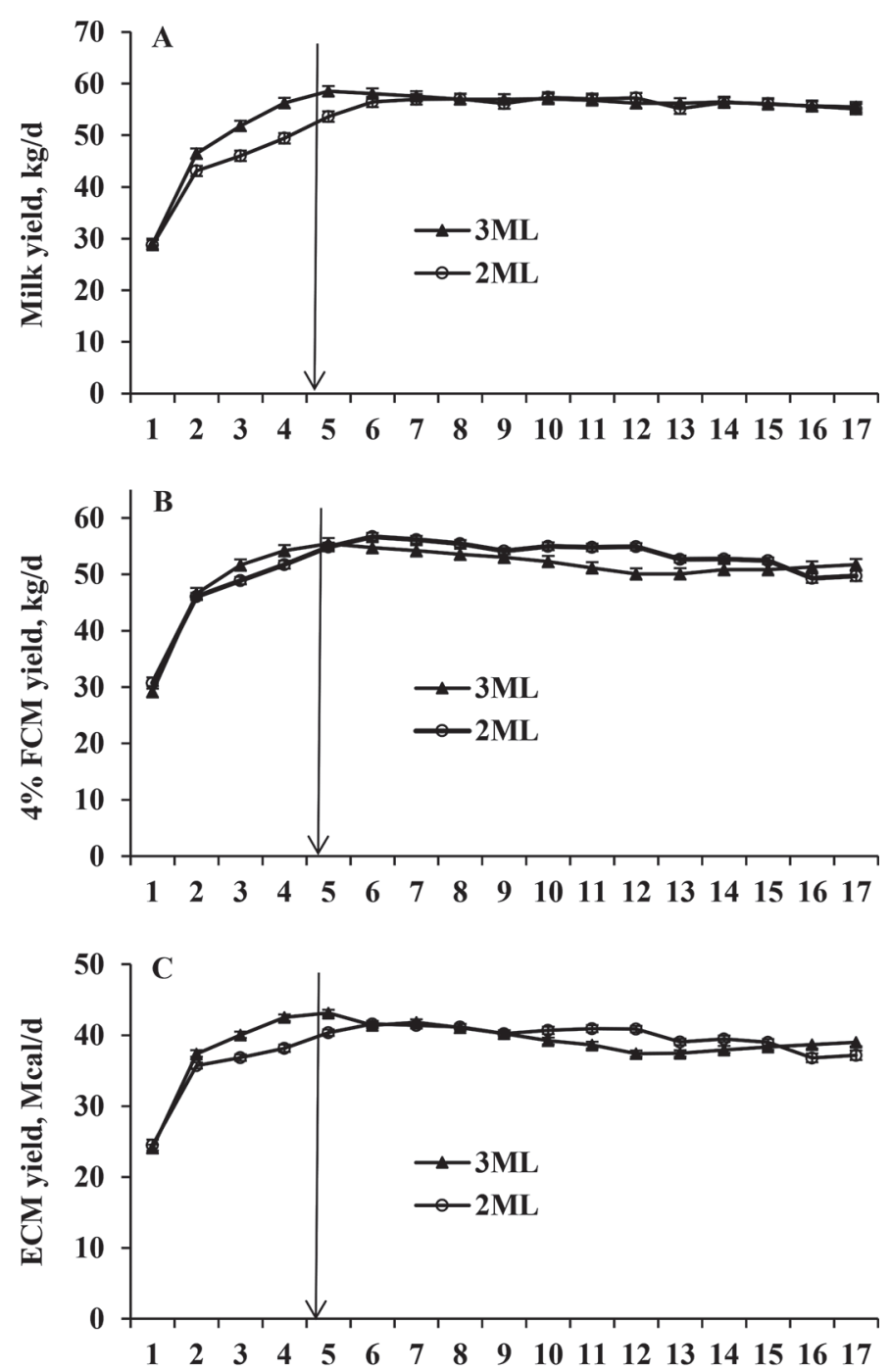

Weeks in lactation

Figure 1. (A) Milk yield, (B) 4\% FCM yield, and (C) ECM yield from calving until 100 DIM for high-yielding dairy cows milked 3 times daily (3ML; $\mathbf{\Delta}$ ) or twice daily (2ML; O) until 30 DIM (vertical arrow) and then milked 3 times daily. Values are LSM, and error bars represent SE. 

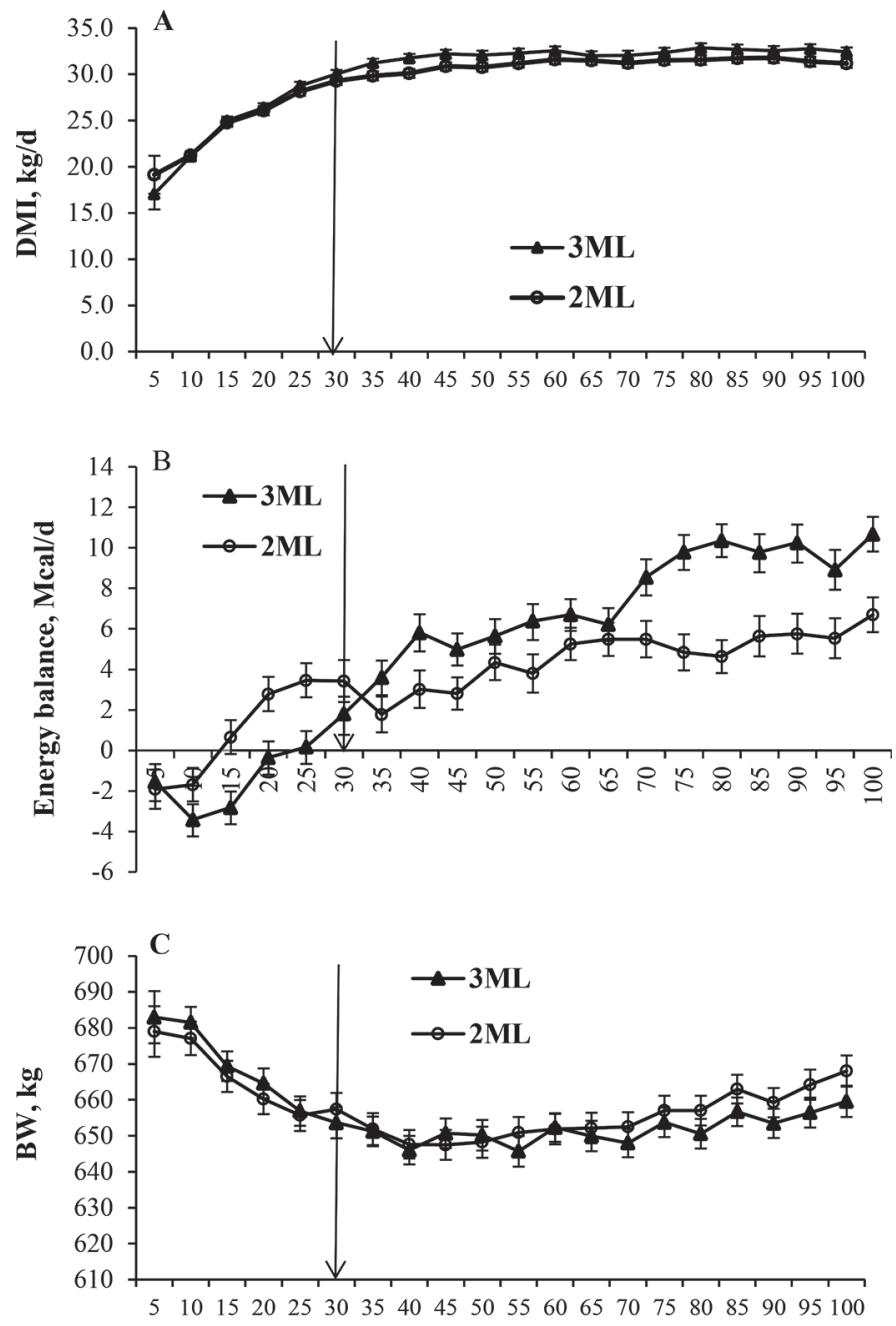

Days relative to calving

Figure 2. (A) Dry matter intake, (B) energy balance, and (C) BW from calving until 100 DIM for high-yielding dairy cows milked 3 times daily (3ML; $\mathbf{\Delta})$ or twice daily $(2 \mathrm{ML} ; 0)$ until 30 DIM (vertical arrow) and then milked 3 times daily. Values are LSM, and error bars represent SE.

interaction were significant $(P=0.02$ and $P<0.001$, respectively). The daily resting time until 30 DIM tended to be higher in the 2ML cows $(P=0.06)$, and from 31 to 100 DIM it was higher in the $2 \mathrm{ML}$ cows $(P$ $<0.001)$. The effects of period and treatment $\times$ period on resting time were significant $(P=0.005$ and $P=$ 0.03 , respectively).

We also analyzed the main production and efficiency results from calving until 100 DIM to determine the overall effect on production (Table 4). Milk yield was not different between groups, but fat percentage was 0.3 percentage units higher in the $2 \mathrm{ML}$ cows than in the 3ML cows $(P<0.001)$. The protein percentage was not different and the lactose content was higher in the 3ML cows than in the 2ML cows $(P=0.04)$. Fat yield was not different, but protein and lactose yields were higher in the $3 \mathrm{ML}$ cows than in the $2 \mathrm{ML}$ cows. The 4\% FCM and ECM yields as well as DMI and EB were not different between groups for 100 DIM. The BW loss from calving to 100 DIM was $27.9 \mathrm{~kg}$ in the $3 \mathrm{ML}$ cows compared with $14.9 \mathrm{~kg}$ in the $2 \mathrm{ML}$ cows $(P$ $=0.12$ ). The $\mathrm{BW}$ gain from 31 to 100 DIM was 17.4 $\mathrm{kg}$ in the $2 \mathrm{ML}$ cows compared with $6.4 \mathrm{~kg}$ in the $3 \mathrm{ML}$ cows $(P=0.03)$. The milk and ECM yields per unit of DMI were not different between groups, but $4 \%$ FCM yield per unit of DMI was $4.1 \%$ higher in the $2 \mathrm{ML}$ cows than in the 3ML cows $(P=0.01)$. On average, the lying time of the $2 \mathrm{ML}$ cows was $38 \mathrm{~min} / \mathrm{d}$ greater than that of the 3ML cows $(P<0.001)$, with no differences in rumination time.

\section{Blood Metabolites}

As presented in Table 5, the plasma glucose concentrations from calving until 30 DIM were $8.9 \%$ higher in the $2 \mathrm{ML}$ cows than in the $3 \mathrm{ML}$ cows $(P=0.001$; Figure $3 \mathrm{~A}$ ) and tended to be higher between 31 and 50 DIM. The plasma BHB concentrations were $12.9 \%$ lower in the $2 \mathrm{ML}$ cows than in the $3 \mathrm{ML}$ cows from 0 to $30 \mathrm{DIM}$ $(P=0.02$; Table 5; Figure 3B), with no differences found later in lactation. The NEFA concentrations from calving until 30 DIM were $34 \%$ higher in the $2 \mathrm{ML}$ cows than in the 3ML cows $(P=0.002$; Figure $3 \mathrm{C})$ and tended to be higher between 31 and 50 DIM. The TG concentrations tended to be higher in the $2 \mathrm{ML}$ cows between 0 and 30 DIM, and the AST concentrations were not affected by MF.

\section{Reproduction System}

The PP ovarian follicular dynamics until 34 DIM are presented in Figure 4. As shown, there was no effect of MF on follicular dynamics until 34 DIM. Two out of 8 cows $(25 \%)$ in the 3ML group developed follicular cysts, whereas no cow in the 2ML group did.

The time at first ovulation was determined by $\mathrm{P}_{4}$ concentrations in plasma; it was found that $10 \%$ of cows from the $3 \mathrm{ML}$ group ovulated $\leq 15$ DIM compared with $40 \%$ of the $2 \mathrm{ML}$ cows $(P<0.03)$. In addition, the first ovulation occurred only at $\geq 30$ DIM in $20 \%$ of the $3 \mathrm{ML}$ cows compared with $5 \%$ of the $2 \mathrm{ML}$ cows $(P<0.1)$.

The size, hormone concentrations, and the content of preovulatory follicles are presented in Table 6. No differences were observed in the size, volume, and $\mathrm{E}_{2}$, $\mathrm{P}_{4}$, or $\mathrm{A}_{4}$ concentrations or the content in preovulatory follicles that were aspirated from 60 to 80 DIM. Although the number of cows used for analyzing the fertility data was small, the fertility performance was 


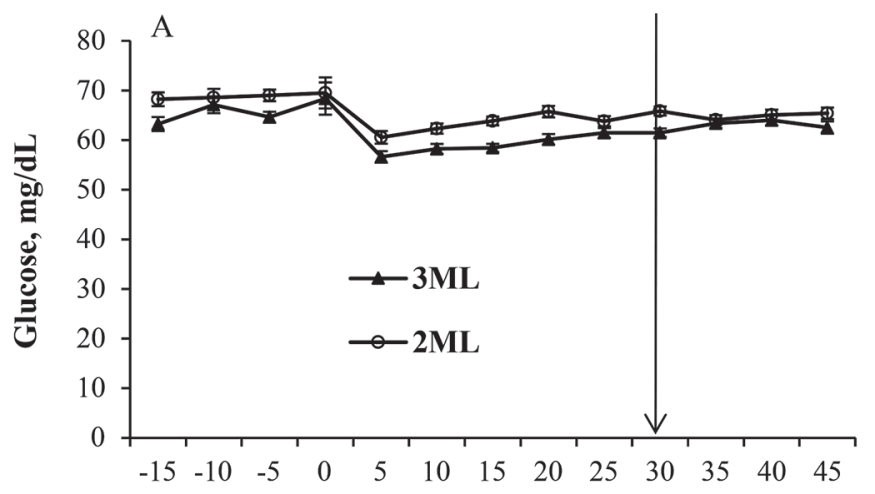

\section{DISCUSSION}

Milking frequency has a great effect on lactation performance in dairy cows, especially at early lactation, and improving EB during early lactation is of great interest. Therefore, in the present study we aimed to improve the metabolic status of high-yielding dairy cows by reducing the MF during the first 30 DIM and to determine the carryover effects. In general, we found a higher milk production in cows milked thrice daily but similar 4\% FCM yield until 30 DIM, with no nega-
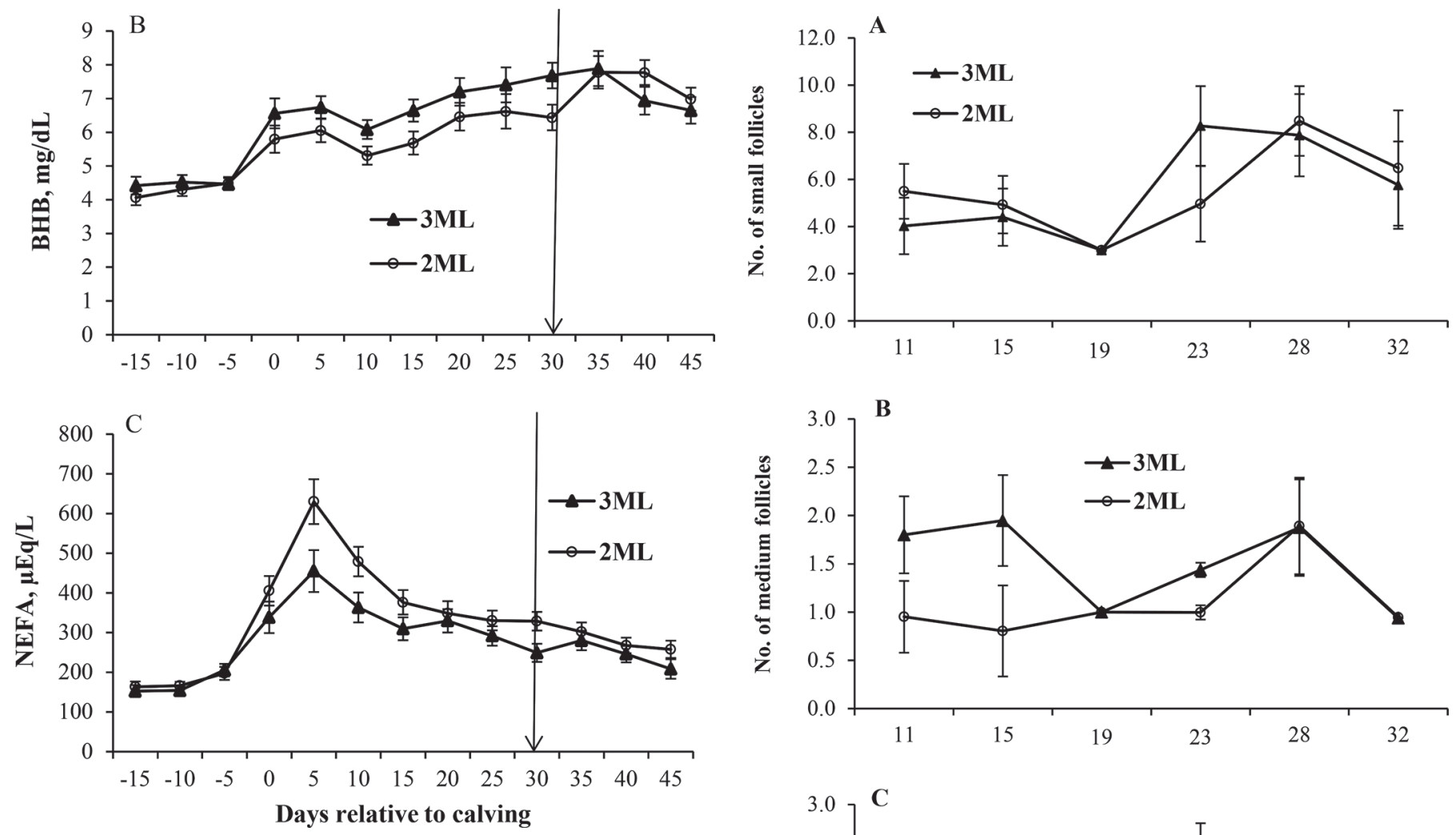

Figure 3. Concentrations of (A) glucose, (B) BHB, and (C) nonesterified fatty acids (NEFA) in blood from $14 \mathrm{~d}$ precalving until 45 DIM for high-yielding dairy cows milked 3 times daily (3ML; $\mathbf{\Delta}$ ) or twice daily (2ML; $)$ ) until 30 DIM (vertical arrow) and then milked 3 times daily. Values are LSM, and error bars represent SE.

higher in the $2 \mathrm{ML}$ cows than in the $3 \mathrm{ML}$ cows. The average days from calving to first detected estrus was 68.0 and $69.4 \mathrm{~d}$ in the $2 \mathrm{ML}$ and 3ML cows, respectively (not significant). The conception rates from the first AI were 50 and $44.4 \%$ and from the second AI were 50 and $40 \%$ in the $2 \mathrm{ML}$ and $3 \mathrm{ML}$ cows, respectively (not significant). In addition, average days open was 9 $\mathrm{d}$ shorter in the $2 \mathrm{ML}$ cows than in the $3 \mathrm{ML}$ cows $(100$ and $109 \mathrm{~d}$, respectively; not significant).

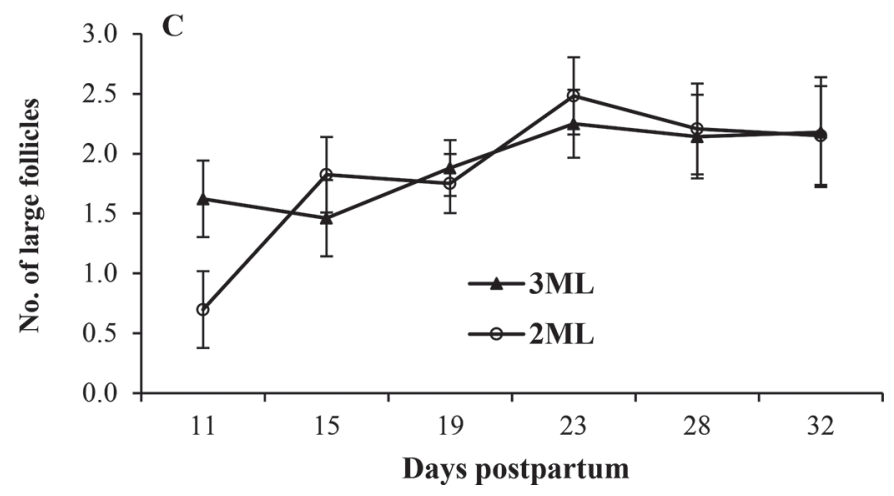

Figure 4. Ovarian follicular development from 10 until 32 DIM of high-yielding dairy cows milked 3 times daily (3ML; $\mathbf{\Delta}$ ) or twice daily (2ML; O) until 30 DIM and then milked 3 times daily. The follicles were divided into 3 categories: (A) 3 to $5 \mathrm{~mm}$ (small), (B) 6 to $9 \mathrm{~mm}$ (medium), and (C) $\geq 10 \mathrm{~mm}$ (large). Values are LSM, and error bars represent SE. 
tive carryover effects on yields until 100 DIM in cows milked twice a day until 30 DIM. The metabolic status of the cows milked twice a day was improved compared with those milked 3 times a day, and the effects of reducing $\mathrm{MF}$ on yield were negligible when considering the yields and efficiency from 0 to 100 DIM. An improvement in EB was observed in the 2ML cows until 30 DIM, with some indications of the beneficial effects on the reproductive system.

\section{MF Effects on Yields}

As mentioned above, Erdman and Varner (1995) summarized data from 19 reports that examined the effect of increasing the MF from twice to thrice daily and found a fixed milk yield response of $3.5 \mathrm{~kg} / \mathrm{d}$ regardless of the yield for those milked twice daily. Interestingly, the results of our study confirm this finding of a fixed milk yield, with cows producing double yields, compared with those reviewed in Erdman and Varner (1995; $\sim 46$ vs. $\sim 22 \mathrm{~kg} / \mathrm{d}$, respectively). Furthermore, whereas the increment increase in milk yield from $2 \times$ to $3 \times$ in our study was $8.6 \%$, in Erdman and Varner (1995) it was as high as $18.3 \%$. This half magnitude in the response in the modern high-yielding cow compared with the low-yielding cow is very interesting with regard to the mechanism underlying the influence of MF on yield and regarding the economic impact of MF. Several studies that examined how increasing MF at early lactation affects yields found positive carryover effects in which milk production remained elevated for a period after the MF treatment was terminated (BarPeled et al., 1995; Hale et al., 2003). In our present study, we did not find any negative carryover effects on yields of reducing MF to twice a day during the first 30 DIM (treatment $\times$ period was significant), and the $2 \mathrm{ML}$ cows closed the gap with the $3 \mathrm{ML}$ cows within 10 $\mathrm{d}$ after shifting to 3 milkings a day.

A sophisticated study by Wall and McFadden (2007) in which a unilateral frequent milking $(2 \times$ vs. $4 \times)$ was conducted concluded that the immediate and carryover effects of frequent milking during early lactation on milk production are regulated locally in the mammary gland. In Hale et al. (2003), cows were milked $2 \times$ or $4 \times$ during the first 3 wk of lactation. A positive carryover effect was found for the remainder of lactation without a significant difference in proliferation. From the aforementioned studies, we can conclude that the effect of frequent milking during early lactation is regulated locally in the mammary gland and that the mammary cell population dynamics are not significantly altered by changes in MF. In most of the studies that examined the effects of increased MF the differences in MF between treatments was at least 2 or sometimes even 3 milkings a day, whereas in our study the difference in MF between groups was only 1 milking $(2 \times$ vs. $3 \times)$. It is possible that the changes in cell turnover in our study were small so that no negative carryover effects occurred for the 2ML cows, and within $10 \mathrm{~d}$ they produced the same high amount as the 3ML cows. In addition, we could not find in the literature a tentative explanation for the fixed milk yield responses of 3.0 to $4.0 \mathrm{~kg} / \mathrm{d}$ upon increasing MF from 2 to 3 milkings a day. Intramammary pressure was suggested as a potential regulator of mammary gland blood flow and milk secretion (Wall and McFadden, 2012). Taking into account the local regulation, it can be assumed that the intramammary pressure of the $2 \mathrm{ML}$ cows during the first 30 DIM was higher than in those milked 3 times a day. However, it is possible that no damage occurred to the secretory cells; therefore, the 2ML cows produced amounts of milk similar to the 3ML cows within 10 $\mathrm{d}$, although this speculation should be elucidated in further studies.

\section{Effect on Milk Solids}

The fat percentage in milk was 7.8 and $5.7 \%$ higher in the $2 \mathrm{ML}$ cows than in the $3 \mathrm{ML}$ cows from 0 to 30 and 31 to 100 DIM, respectively. The decrease in milk fat content with increasing MF was found in many previous studies (Bar-Peled et al., 1995; Erdman and Varner, 1995; Hale et al., 2003; Soberon et al., 2011) but not by Wall and McFadden (2007). The trend of higher milk fat content in the $2 \mathrm{ML}$ cows after shifting to $3 \times$ milking (31-100 DIM) was also found by Hale et al. (2003). However, fat yield was higher in the 3ML cows during the first 30 DIM, a trend that was also found by Alex et al. (2015) but not by Hale et al. (2003) with increasing MF. The higher fat percentage in the $2 \mathrm{ML}$ cows could be explained by the $8.6 \%$ lower milk yield in these cows compared with the 3ML cows. However, the higher milk fat content in the $2 \mathrm{ML}$ cows from 31 to 100 DIM occurred even though the milk yields of both groups were similar, which demonstrates a positive carryover effect (treatment $\times$ period was not significant) of the lower MF until 30 DIM on fat synthesis later in lactation.

No differences in the protein percentage in milk were observed between groups during the treatment period (until 30 DIM) or from 31 to 100 DIM. This was similar to the results of Hale et al. (2003) and Wall and McFadden (2007); however, in a study with an increased MF on the mean half-udder, Alex et al. (2015) found a higher protein percentage in the increased $(4 \times) \mathrm{MF}$ compared with $1 \times$ milking. Because of the higher milk 
yields, the protein yields $(\mathrm{kg} / \mathrm{d})$ were higher in the $3 \mathrm{ML}$ cows during the first 30 DIM but not from 31 to 100 DIM.

Despite the differences in milk, 4\% FCM was similar between groups during the treatment period, and from 31 to 100 DIM it was even higher (5.1\%) in the 2ML cows than in the $3 \mathrm{ML}$ cows. The energy output in milk was higher in the 3ML cows during the first 30 DIM, but from 31 to 100 DIM it was higher in the 2ML cows. Unfortunately, the FCM and ECM yields were not reported in most studies that investigated the effect of MF on yields; these yields are crucial parameters for evaluating whether the differences in milk production lie only in the milk volume or in the production potential of the cows in terms of energy output. According to our results, the differences between the $2 \mathrm{ML}$ and $3 \mathrm{ML}$ cows were mainly in the milk volume, and to a lesser extent in the total production potential, which includes the solid content in milk. This may have important economic considerations because in most countries the payment for milk includes a combination of the milk volume and the solids content. For example, according to the Israeli formula for milk payment, the average yields from 0 to 100 DIM were numerically higher in the $2 \mathrm{ML}$ cows than in the $3 \mathrm{ML}$ cows $(51.9$ vs. 51.3 $\mathrm{kg} / \mathrm{d}$, respectively).

An analysis of the whole study period (0-100 DIM) revealed no difference between groups regarding milk, $4 \%$ FCM, and ECM yields and protein percentage; however, the fat percentage and yields were higher in the $2 \mathrm{ML}$ cows, and the protein and lactose yields were higher in the 3ML cows. In addition, the efficiency in FCM production (FCM/DMI) was higher in the 2ML cows than in the 3ML cows. These results indicated minor effects on production when reducing the MF to twice a day during the first 30 DIM. Moreover, the economic benefits of reducing MF become noteworthy when taking into consideration the additional savings regarding manpower, electricity, and the physical deterioration of facilities when milking twice daily at early lactation compared with thrice daily.

\section{Metabolic Status of the Cows}

The main goal of this study was to improve the metabolic status of cows during early lactation by reducing the MF. Indeed, the glucose plasma concentrations were higher and the $\mathrm{BHB}$ concentrations were lower in the 2ML cows during the first period (0-30 DIM), which is in agreement with the positive $\mathrm{EB}$ of the $2 \mathrm{ML}$ cows compared with the $3 \mathrm{ML}$ cows. Increasing the MF at early lactation in Bar-Peled et al. (1998) from 3 to 6 times a day increased milk yield by $22 \%$ but decreased glucose concentrations and increased NEFA plasma concentrations. In a study by Rastani et al. (2005), eliminating the dry period decreased milk yield by $20 \%$ but improved EB and the metabolic status of the cows compared with cows with a traditional dry period length. However, in our present study, the metabolic status of the cows was improved with a smaller reduction in milk yields, with no negative carryover effects. Additionally, the 2ML cows rested (lying time) on average $38 \mathrm{~min} / \mathrm{d}$ more than the $3 \mathrm{ML}$ cows.

Interestingly, although the glucose and BHB concentrations in blood indicated an improvement in the metabolic status of the 2ML cows, NEFA concentrations were higher in this group, which may indicate greater body mass mobilization in the $2 \mathrm{ML}$ cows. However, the BW loss from calving to wk 5 was not different between groups. The blood concentration of a metabolite is the equilibrium between the release and clearance from the blood stream. Because a great part of the released NEFA in the high-yielding dairy cow is transported to the mammary gland for milk fat synthesis, it can be assumed that the higher NEFA in the 2ML cows occurs because of the lesser clearance compared with the $3 \mathrm{ML}$ cows.

The EB from 31 to 100 DIM was greater in the 3ML cows than in the $2 \mathrm{ML}$ cows. This was primarily because the increase in ECM yield from the first to the second period in the 2ML cows was $19 \%$ compared with $9.3 \%$ in the 3ML cows, whereas the increase in intake was almost similar $(11.2 \%$ in the $2 \mathrm{ML}$ cows vs. $13.3 \%$ in the 3ML cows). Capuco et al. (2001) found that during early lactation, the milk secretion, which increased to peak levels, was due to the continued differentiation of the mammary secretory cells and the increased secretory activity per cell; however, no net mammary growth was observed. It can be assumed that the increase in milk yield from milking 2 times to milking 3 times a day after 30 DIM in the 2ML group was mainly due to an increase in the secretory capacity of the cells rather than to an increase in the mammary gland mass. The intake of the $2 \mathrm{ML}$ cows was similar to that of the $3 \mathrm{ML}$ cows, and the curve shape (Figure 2A) was identical between groups, which means that perhaps the capacity of the digestive tract was at the maximum level in both groups and therefore the EB of the $2 \mathrm{ML}$ cows was lower from 31 to 100 DIM. Both groups were in positive EB during the second period of the study.

\section{Reproductive System}

Many studies have been published investigating the association among yields, EB, and fertility (Butler and Smith, 1989; Heravi Moussavi et al., 2007; Cheong et al., 2016). One of the main effects of negative EB is delayed resumption of ovulation and cyclicity PP. Early 
resumption of ovarian cyclicity $\mathrm{PP}$ has been associated with improved reproductive performance (Galvão et al., 2010). Indeed, cows ovulating before $21 \mathrm{~d}$ PP had better subsequent reproductive performance than those ovulating for the first time between 21 and $49 \mathrm{~d}$ PP (Galvão et al., 2010). In our present study, more cows in the 2ML group ovulated before 15 DIM compared with the 3ML cows, which is in line with the improved $\mathrm{EB}$ in the former cows. However, although there is evidence of earlier ovulation in the 2ML cows, no differences were observed in the characteristics of preovulatory follicles aspirated from 60 to 80 DIM. This could be explained by the EB of the 3ML cows, which was higher than that of the 2ML cows from 31 DIM and later, which could have compensated for the earlier NEB in this group.

\section{CONCLUSIONS}

Reducing the MF from thrice to twice daily from calving until 30 DIM had beneficial effects on EB and the metabolic status of high-yielding dairy cows and only minor effects on production. Furthermore, the results of the present study confirm the fixed milk yield increase with increasing MF from twice to thrice reported by Erdman and Varner (1995). Although the milk yield level was doubled, the 3 to $4 \mathrm{~kg} / \mathrm{d}$ difference was maintained, which means that the proportion of the decrease with reducing MF is diminished in high-yielding cows. No negative carryover effects were observed, and the $2 \mathrm{ML}$ cows closed the gap in yields within $10 \mathrm{~d}$ after shifting to 3 milkings. There was also an indication of earlier PP ovulation without positive effects on preovulatory follicles aspirated from 60 to 80 DIM. It can be concluded that reducing the MF to twice a day during the first 30 DIM and then increasing it to 3 times daily may benefit the metabolic status of high-yielding dairy cows, with negligible effects on milk production.

\section{ACKNOWLEDGMENTS}

This research was financially supported by the Israeli Dairy Board, Yehud, Israel (grant number 362-0449-16). The authors thank the entire staff of the experimental dairy farm at the Volcani Center, Rishon LeZion, Israel, for their assistance with animal care.

\section{REFERENCES}

Alex, A. P., J. L. Collier, D. L. Hadsell, and R. J. Collier. 2015. Milk yield differences between $1 \times$ and $4 \times$ milking are associated with changes in mammary mitochondrial number and milk protein gene expression, but not mammary cell apoptosis or SOCS gene expression. J. Dairy Sci. 98:4439-4448.
AOAC. 1990. Official Methods of Analysis. Association of Official Analytical Chemists, Arlington, VA.

Bar-Peled, U., Y. Aharoni, B. Robinzon, I. Bruckental, R. Lehrer, E. Maltz, C. Knight, J. Kali, and Y. Folman. 1998. The effect of enhanced milk yield of dairy cows by frequent milking or suckling on intake and digestibility of the diet. J. Dairy Sci. 81:1420-1427.

Bar-Peled, U., E. Maltz, I. Bruckental, Y. Folman, Y. Kali, H. Gacitua, A. R. Lehrer, C. H. Knight, B. Robinzon, and H. Voet. 1995. Relationship between frequent milking or suckling in early lactation and milk production of high producing dairy cows. J. Dairy Sci. 78:2726-2736.

Beam, S. W., and W. R. Butler. 1998. Energy balance, metabolic hormones, and early postpartum follicular development in dairy cows fed prilled lipid. J. Dairy Sci. 81:121-131.

Bernal-Santos, G., J. W. Perfield II, D. M. Barbano, D. E. Bauman, and T. R. Overton. 2003. Production responses of dairy cows to dietary supplementation with conjugated linoleic acid (CLA) during the transition period and early lactation. J. Dairy Sci. 86:3218 3228.

Bertics, S. J., and R. R. Grummer. 1999. Effects of fat and methionine hydroxy analog on prevention or alleviation of fatty liver induced by feed restriction. J. Dairy Sci. 82:2731-2736.

Butler, S. T., S. H. Pelton, and W. R. Butler. 2006. Energy balance, metabolic status, and the first PP ovarian follicle wave in cows administered propylene glycol. J. Dairy Sci. 89:2938-2951.

Butler, W. R. 2003. Energy balance relationships with follicular development, ovulation and fertility in postpartum dairy cows. Livest. Prod. Sci. 83:211-218.

Butler, W. R., and R. D. Smith. 1989. Interrelationships between energy balance and postpartum reproductive function in dairy cattle. J. Dairy Sci. 72:767-783.

Capuco, A. V., D. L. Wood, R. Baldwin, K. Mcleod, and M. J. Paape. 2001. Mammary cell number, proliferation, and apoptosis during a bovine lactation: Relation to milk production and effect of bST. J. Dairy Sci. 84:2177-2187.

Castañeda-Gutiérrez, E., T. R. Overton, W. R. Butler, and D. E. Bauman. 2005. Dietary supplements of two doses of calcium salts of conjugated linoleic acid during the transition period and early lactation. J. Dairy Sci. 88:1078-1089.

Cheong, S. H., O. G. Sá Fliho, V. A. Absalón-Medina, S. H. Pelton, W. R. Butler, and R. O. Gilbert. 2016. Metabolic and endocrine differences between dairy cows that do or do not ovulate first postpartum dominant follicles. Biol. Reprod. 94:18.

Chilliard, Y. 1993. Dietary fat and adipose tissue metabolism in ruminants, pigs, and rodents: A review. J. Dairy Sci. 76:3897-3931.

Edmonson, A. J, I. J. Lean, L. D. Weaver, T. Farver, and G. Webster. 1989. A body condition scoring chart for Holstein dairy cows. J. Dairy Sci. 72:68-78.

Erdman, R. A., and M. Varner. 1995. Fixed yield responses to increased milking frequency. J. Dairy Sci. 78:1199-1203.

Esposito, G., C. P. Irons, E. C. Webb, and A. Chapwanya. 2014. Interactions between negative energy balance, metabolic diseases, uterine health and immune response in transition dairy cows. Anim. Reprod. Sci. 144:60-71.

Galvão, K. N., M. Frajblat, W. R. Butler, S. B. Brittin, C. L. Guard, and R. O. Gilbert. 2010. Effect of early postpartum ovulation on fertility in dairy cows. Reprod. Domest. Anim. 45:e207-e211.

Grummer, R. R. 1993. Etiology of lipid-related metabolic disorders in periparturient dairy cows. J. Dairy Sci. 76:3882-3896.

Grummer, R. R., and R. R. Rastani. 2004. Why reevaluate dry period length? J. Dairy Sci. 87(Suppl.):E77-E85.

Gümen, A., R. R. Rastani, R. R. Grummer, and M. C. Wiltbank. 2005. Reduced dry periods and varying prepartum diets alter postpartum ovulation and reproductive measures. J. Dairy Sci. 88:2401-2411.

Hale, S. A., A. V. Capuco, and R. A. Erdman. 2003. Milk yield and mammary growth effects due to increased milking frequency during early lactation. J. Dairy Sci. 86:2061-2071.

Heravi Moussavi, A. R., R. O. Gilbert, T. R. Overton, D. E. Bauman, and W. R. Butler. 2007. Effects of feeding fish meal and n-3 fatty 
acids on ovarian and uterine responses in early lactating dairy cows. J. Dairy Sci. 90:145-154.

IDF (International Dairy Federation). 2000. IDF Standard 141c:2000 (Determination of milk fat, protein and lactose content - Guidance on the operation of mid-infrared instruments. International Dairy Federation, Brussels, Belgium.)

Ireland, J. J., and F. Roche. 1982. Development of antral follicles in cattle after prostaglandin-induced luteolysis: Changes in serum hormones, steroids in follicles fluids and gonadotropin receptors. Endocrinology 111:2077-2086.

Leroy, J. L., R. G. Sturmey, V. Van Hoeck, J. De. Bie, P. J. McKeegan, and P. E. Bols. 2014. Dietary fat supplementation and the consequences for oocyte and embryo quality: Hype or significant benefit for dairy cow reproduction? Reprod. Domest. Anim. 49:353-361.

Lucy, M. C. 2001. Reproductive loss in high-producing dairy cattle: Where will it end? J. Dairy Sci. 84:1277-1293.

Moallem, U., Y. Folman, A. Bor, A. Arav, and D. Sklan. 1999. Effect of calcium soaps of fatty acids and administration of somatotropin on milk production, preovulatory follicular development, and plasma and follicular fluid lipid composition in high yielding dairy cows. J. Dairy Sci. 82:2358-2368.

Moallem, U., M. M. Katz, A. Arieli, and H. Lehrer. 2007. Effects of peripartum propylene glycol or fats differing in fatty acid profiles on feed intake, production, and plasma metabolites in dairy cows. J. Dairy Sci. 90:3846-3856.

Morrow, D. A. 1976. Fat cow syndrome. J. Dairy Sci. 59:1625-1629.

National Research Council. 1989. Nutrient Requirements of Dairy Cattle. 6th ed. Natl. Acad. Sci., Washington, DC.

National Research Council. 2001. Nutrient Requirements of Dairy Cattle. 7th rev. ed. National Academy Press, Washington, DC.
Rastani, R. R., R. R. Grummer, S. J. Bertics, A. Gümen, M. C. Wiltbank, D. G. Mashek, and M. C. Schwab. 2005. Reducing dry period length to simplify feeding transition cows: Milk production, energy balance, and metabolic profiles. J. Dairy Sci. 88:1004-1014.

SAS Institute. 2002. SAS User's Guide: Statistics. Version 9.2. SAS Institute Inc., Cary, NC.

Shingfield, K. J., D. E. Beever, C. K. Reynolds, S. K. Gulati, D. J. Humphries, B. Lupoli, G. Hervás, and J. M. Griinari. 2004. Effect of rumen protected conjugated linoleic acid on energy metabolism of dairy cows during early to mid-lactation. J. Dairy Sci. 87(Suppl. 1):307. (Abstr.)

Sklan, D., U. Moallem, and Y. Folman. 1991. Effects of feeding calcium soaps of fatty acids on production and reproduction responses in high production lactating cows. J. Dairy Sci. 74:510-517.

Soberon, F., C. M. Ryan, D. V. Nydam, D. M. Galton, and T. R. Overton. 2011. The effects of increased milking frequency during early lactation on milk yield and milk composition on commercial dairy farms. J. Dairy Sci. 94:4398-4405.

Van Soest, P. J., J. B. Robertson, and B. A. Lewis. 1991. Methods for dietary fiber, neutral detergent fiber, and nonstarch polysaccharides in relation to animal nutrition. J. Dairy Sci. 74:3583-3597.

Wall, E. H., and T. B. McFadden. 2007. The milk yield response to frequent milking in early lactation of dairy cows is locally regulated. J. Dairy Sci. 90:716-720.

Wall, E. H., and T. B. McFadden. 2012. How the mammary gland adapts to changes in milking frequency. J. Anim. Sci. 90:16951707. 